M. Сунгуровський (керівник проекту) та ін. Київ : Заповіт, 2018. 60 с. URL: http://razumkov. org.ua/uploads/article/2018_poriv_analiz_pozycii_vlady.pdf

12. Теорія та практика публічної служби : матеріали наук.-практ. конф., Дніпро, 21 грудня 2018 р. / за заг. ред. С.М. Серьогіна. Дніпро : ДРІДУ НАДУ, 2018. 265 с. URL: http://dridu.dp.ua/konf/konf_dridu/2018_12_21_material_dums.pdf

13. Стан системи професійного навчання державних службовців, голів місцевих державних адміністрацій, їх перших заступників та заступників, посадових осіб місцевого самоврядування, депутатів місцевих рад : доповідь / К. Ващенко (кер. авт. колективу) та ін. ; за заг. ред. К. Ващенка. Київ : Центр адаптації державної служби до стандартів Свропейського Союзу, 2019. 140 c. URL: https://nads.gov.ua/storage/app/sites/5/професійне\%20навчання/preview_2019-07-16_block_dopovid_170x240.pdf

14. Постанова Кабінету Міністрів України від 24.06.2016 року № 386 «Про внесення зміни до пункту 1 постанови Кабінету Міністрів України від 9 березня 2006 року № 268. URL: https://zakon.rada.gov.ua/laws/show/386-2016-п

15. Янюк Н.В. Законодавство про службу в органах місцевого самоврядування: позиції з удосконалення. URL: file:///C:/downloads/Chkup_2015_4_23.pdf

16. Постанова Кабінету Міністрів України від 6 лютого 2019 р. № 106 Про затвердження Положення про систему професійного навчання державних службовців, голів місцевих державних адміністрацій, їх перших заступників та заступників, посадових осіб місцевого самоврядування та депутатів місцевих рад. URL: https://zakon.rada.gov.ua/laws/ show/106-2019-п

17. Закон України «Про місцеве самоврядування в Україні». URL: https://zakon.rada. gov.ua/laws/show/280/97-вр

ZABOKRYTSKYY I. I.,

Candidate of Juridical Sciences (PhD), Associate Professor of the Department of Constitutional and International law (Institute of Law, Psychology and Innovative Education of Lviv Polytechnic National University)

DOI https://doi.org/10.32842/2078-3736/2020.1-1.7

\title{
EUROPEAN INTEGRATION OF UKRAINE IN THE CONTEXT OF TRANSNATIONALIZATION OF MODERN CONSTITUTIONALISM
}

The article analyzes the European integration of Ukraine in the context of transnationalization of modern constitutionalism. It is concluded that there has been an increase in European integration processes in Ukraine since 2014, which is connected with the signing of the Association Agreement between Ukraine and the European Union. We can distinguish the following areas in which the process of European integration is taking place: (1) the amendments to the Constitution of Ukraine; (2) creation of institutional mechanisms for European integration, which can be divided into (i) external ones, through which Ukraine and the EU cooperate on

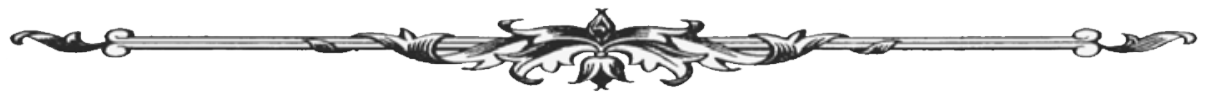


issues such as the EU-Ukraine Summit, the Association Council and the Association Committee; and (ii) internal ones created within the Ukrainian Parliament and the Government to pay attention and verify compliance with the Association Act, which is being adopted - is the post of Vice Prime Minister for European and Euro-Atlantic Integration, a government office Coordination of European and Euro-Atlantic Integration, Governmental Committee on European, Euro-Atlantic Integration, International Cooperation, and Regional Development, Verkhovna Rada of Ukraine Committee on European Integration and Minister for European Integration, Directorate of Strategic Planning and European integration; (3) creation of legal mechanisms within the framework of lawmaking, such as the obligatory review of acts of the Cabinet of Ministers of Ukraine for compliance with Ukraine's commitments in the field of European integration and the European Union law (EU acquis); (4) adoption of action plans at the level of the Cabinet of Ministers of Ukraine and the President of Ukraine for the implementation of the Association Agreement; (5) Implementation of measures on the implementation of the Association Agreement, adoption of necessary laws.

Key words: European integration, constitutionalism, transnationalization of constitutionalism, Association between Ukraine and the EU.

Забокрицький I. I. Європейська інтеграція України в контексті транснаціоналізації сучасного конституціоналізму

У статті проаналізовано євроінтеграцію України в контексті транснаціоналізації сучасного конституціоналізму. Зроблено висновок, що в Україні спостерігається посилення процесів євроінтеграції з 2014 року, що пов'язано $з$ підписанням Угоди про асоціацію між Україною та Європейським Союзом. Можна виділити такі сфери, в яких відбувається процес європейської інтеграції: (1) зміни до Конституції України; (2) створення інституційних механізмів європейської інтеграції, які можна розділити на а) зовнішні, за допомогою яких Україна та $Є С$ співпрацюють у таких питаннях, як саміт Україна- $С$, Рада асоціації та Комітет асоціації; та б) внутрішні, створені в парламенті України та уряді, щоб звернути увагу й перевірити відповідність Закону про асоціацію, який приймається, - це посада віце-прем'єр-міністра 3 питань європейської та євроатлантичної інтеграції, урядовий офіс координації європейської та євроатлантичної інтеграції, урядовий комітет з питань європейської, євроатлантичної інтеграції, міжнародного співробітництва та регіонального розвитку, комітет Верховної Ради України з питань європейської інтеграції, посади заступника міністра 3 питань європейської інтеграції, директорати стратегічного планування та європейської інтеграції.; (3) створення правових механізмів у межах законотворчої діяльності, таких як обов'язковий перегляд актів Кабінету Міністрів України на предмет дотримання зобов'язань України у сфері європейської інтеграції та права Європейського Союзу (Acquis $\mathrm{CC}$ ); (4) прийняття планів дій на рівні Кабінету Міністрів України та Президента України щодо імплементації Угоди про асоціацію; (5) Здійснення заходів щодо імплементації Угоди про асоціацію, прийняття необхідних законів.

Ключові слова: європейська інтеграчія, конституціоналізм, транснаціоналізація конституціоналізму, асочіаџія між Україною та ЄС.

Formulation of the problem. Although the issue of European integration has been raised in our country since independence, it has intensified since the Revolution of Dignity and the signing of the Association Agreement between Ukraine and the EU [1]. One of the main principles of foreign policy is to ensure the integration of Ukraine into the European political, economic and legal space

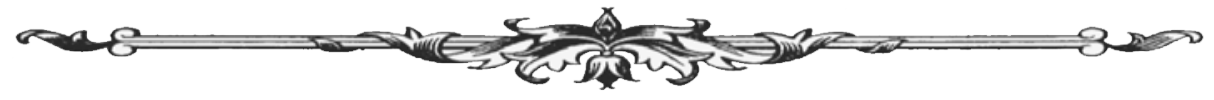


in order to become a member of the European Union (Part 2 of Article 11 of the Law of Ukraine "On the principles of domestic and foreign policy") [2]. Moreover, in 2019, these principles were also enshrined at the constitutional level by adopting the Law of Ukraine "On Amendments to the Constitution of Ukraine (concerning the strategic course of the state for the acquisition of full membership of Ukraine in the European Union and the North Atlantic Treaty Organization") [3]. So, there is a need to examine more deeply the European integration of Ukraine in the context of transnationalization of modern constitutionalism.

Thus, the study objectiove of this articlet is European integration of Ukraine in the context of transnationalization of modern constitutionalism.

Study Results. As we mentioned above, in 2019 the following major changes were made to the Constitution of Ukraine with the Law of Ukraine "On Amendments to the Constitution of Ukraine (concerning the strategic course of the state for the acquisition of full membership of Ukraine in the European Union and the North Atlantic Treaty Organization") [3]:

1. Part 5 of the preamble was supplemented with the words "and confirming the European identity of the Ukrainian people and the irreversibility of the European and Euro-Atlantic course of Ukraine" - thus, the preamble to the Constitution has enshrined the irreversibility of the course on the European integration;

2. The powers of the Verkhovna Rada of Ukraine include implementation of the strategic course of the state for the acquisition of full membership of Ukraine in the European Union and the North Atlantic Treaty Organization (Article 85, paragraph 5);

3. Part 2 of Art. 102 of the Constitution of Ukraine establishes that the President of Ukraine is a guarantor of the implementation of the strategic course of the state for full membership in the European Union and the North Atlantic Treaty Organization;

4. It is established that the Cabinet of Ministers of Ukraine ensures the implementation of the strategic course of the state for the acquisition of full membership in the European Union and the North Atlantic Treaty Organization (Clauses 1-1 of Article 116 of the Constitution of Ukraine).

Thus, by amending the Constitution of Ukraine, the strategic course of the state for full membership in the European Union was not only enshrined as a general basis but also introduced as an obligation of the Verkhovna Rada, the President of Ukraine and the Cabinet of Ministers of Ukraine, which would promote as much attention to these issues and the need to apply the Constitution of Ukraine as a norm of direct action.

Although the Constitutional Court of Ukraine gave a positive Opinion [4] on this draft Law of Ukraine, which was subsequently adopted, six Separate Opinions of Judges of the Constitutional Court of Ukraine were provided about it. Thus, according to judge Hultai, the changes regarding the powers of the Verkhovna Rada of Ukraine, the Cabinet of Ministers of Ukraine and the status of the President of Ukraine contain legal uncertainty, since they have a common wording and can lead to an imbalance of the mechanism of exercising state power [5]. However, in our opinion, we do not see any threat of imbalance in this case, as simply fixing such a course would not be enough - it is important to fix the course not only declaratively, but also within the scope of specific powers. In addition, the balance in terms of the distribution of power is not disturbed also because new powers have not been added - the implementation of the strategic course should be carried out within the existing powers.

Judge Melnyk, among other things, draws attention to the inappropriateness of amending the Preamble, since it is a specific part of the Constitution and it records the historic moment of its adoption, which was a one-time act. Judge Melnyk also believes that it would be advisable to amend Art. 18 of the Constitution of Ukraine, reflecting the foundations of Ukraine's foreign policy activity [6]. In support of Judge Melnik's opinion in general, we consider that, under the current conditions, amendments to Art. 18, which is contained in Section I of the Constitution of Ukraine and which would require further approval in an all-Ukrainian referendum, did not look realistic from a practical point of view. Instead, if Ukraine becomes a member of the European Union, it will require the transfer of part of its sovereign powers to it, and therefore it will also need to

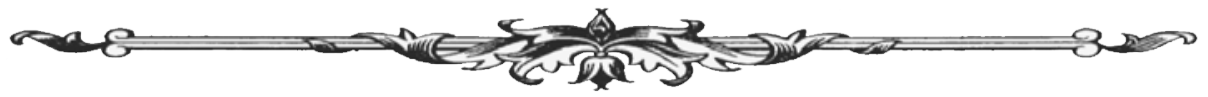


amend Section I. Instead, at the current stage, only a course on European integration is being fixed that can take place even without the compulsory acquisition of formal membership in the EU, but by implementing the provisions of the Association Agreement and meeting the necessary criteria. In addition, Judge Melnyk considers it inappropriate to attach the names of specific interstate entities - the European Union and the North Atlantic Treaty Organization, since their name, reorganization, termination, etc., may be changed, and in such a case it will require further amendment of the Constitution, referring to the previous practice of the Constitutional Court of Ukraine, which stated that "the existence of too detailed provisions in the Constitution of Ukraine, which are in the current legislation, will create the need for frequent amendments to it, which will adversely affect the stability of the Basic Law" (paragraph 1, paragraph 4, of the motivating part of the Opinion of 2 June 1999 No. 2-v / 99 [7]) [6]. In our view, despite the general correctness of the provisions and the need to avoid excessive detailing of these provisions, it is unlikely that the name change of the European Union seems real in the near future, and therefore there is no significant threat to constitutional stability ${ }^{1}$.

Judge Pervomaiskyi, in turn, has a more lenient view of amending the Preamble, pointing out that since the provisions of the Constitution of Ukraine do not contain either a direct indication of the possibility or a prohibition of amending the Preamble, therefore the Constitutional Court of Ukraine had to state its own legal position about this question (p. 1 of his Opinion [10]). In addition, Judge Pervomaiskiy cites a number of other arguments that he believes should be contained in the Constitutional Court's Opinion, including the need to analyze the practice of foreign states regarding the constitutional fixing of the provisions on European integration, and cites the experience of such states as Montenegro, Bulgaria, Hungary, Croatia, Romania, Poland, Estonia, Portugal, France and Germany (paragraph 10 of the Opinion) [10]. Judge Tupitskyi also expressed his opinion on the possibility of amending the Preamble to the Constitution of Ukraine, as well as the need for holding an all-Ukrainian referendum [11].

From the analyzed above the opinion of the Constitutional Court of Ukraine and the opinion of judges of the Constitutional Court, we see that the main observations relate to the possibility of amending the Preamble, as well as the need to amend Section I of the Constitution of Ukraine, which is possible only in the complicated procedure of holding an all-Ukrainian referendum. We believe that the issue of amending the Preamble is debatable and may be the subject of a separate study. The main argument for the possibility of amendment is the fact that the Preamble is an integral part of the Constitution, as well as the absence of a ban on amending the Preamble. With regard to the proponents of the position that amendments to the Preamble cannot be made, their main arguments come down to the special nature of the Preamble, which has a historic and one-time nature, due to the circumstances of the adoption of the Constitution and the exercise of the constituent power of the people. Regarding the need to consolidate the course for membership of the European Union exclusively in section I of the Constitution, we believe that this is not mandatory at this stage. Firstly, such a course can be (and is) a definite and ordinary law of Ukraine, such as the Law of Ukraine "On the Principles of Domestic and Foreign Policy". Secondly, the need for such a course stems from the international obligations of Ukraine, in particular, the Association Agreement, which is part of the national legislation due to the requirements of Art. 9 of the Constitution of Ukraine. Third, the amendments to the Constitution of Ukraine at this stage relate (in addition to discussing changes to the Preamble) the powers and status of the President of Ukraine, the Verkhovna Rada of Ukraine and the Cabinet of Ministers of Ukraine, and these amendments were adopted by the Verkhovna Rada of Ukraine as representatives of the people elected in the democratic and free elections, in accordance with the procedure laid down in the Constitution of Ukraine. At this stage,

1 Judge Kasminin also expressed similar views, arguing that it is impossible to amend the Preamble to the Constitution of Ukraine due to the lack of the procedure for amending it, and also asserting that people have the right to determine the foreign policy activity of Ukraine, which, according to the prescriptions of the Constitution of Ukraine holding an all-Ukrainian referendum [8]. The criticism of amending the Preamble to the Constitution of Ukraine is supported by Judge Lytvynov in his Opinion, who claims that the consolidation in the Preamble of the irreversibility of the European and Euro-Atlantic course of Ukraine encroaches on the sovereign right of the people to change the constitutional order of Ukraine [9].

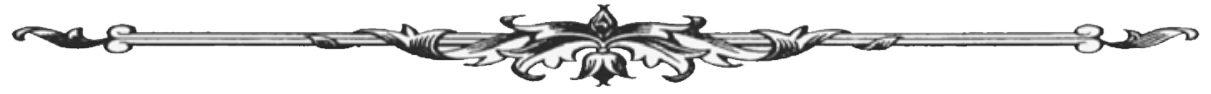


there is no practical need to amend Section I of the Constitution of Ukraine, and therefore we do not support the arguments both about the violation of the balance of power and the encroachment on the sovereign right of the Ukrainian people, since, in this case, the amendments were made within and in the way provided for in the Constitution.

Thus, the course on European integration is provided not only by the legislation of Ukraine and the Association Agreement but also at the level of the Constitution of Ukraine. The key objective of such a course is to implement the Association Agreement, which has become the subject of both scientific research and practical implementation. The implementation of the Association Agreement in various contexts is being explored by a number of Ukrainian scholars, such as I.S. Demchenko (in the context of the prospects of the Association Agreement between Ukraine and the EU [12]), O.V. Chernadchuk (on administrative and legal bases of implementation of the economic part of the Ukraine-EU Agreement [13]), K.A. Ragulina (on the Association Agreement as a legal basis for the adaptation of the legislation of Ukraine to the legislation of the European Union [14]), I. Yavorska (in the context of the legal bases for the implementation of the Association Agreement with the European Union in the sphere of regulation of partnerships [15]), L.V. Melekh (on some issues of implementation of the European Union legislation in the land legislation of Ukraine [16]), T. Podorozhnia (on problems of updating the Constitution of Ukraine and national legislation in the context of signing the Association Agreement between Ukraine and the EU [17]), M.V. Bilak (in the context of the study "The Importance of the Association Agreement with the EU: New Challenges to the Constitutional Order or a Weakening of the Position of the Basic Law" [18]) and others. As we can see, European integration in general and the Association Agreement, in particular, are considered in the context of very diverse issues, since the Agreement itself concerns many areas that require its implementation and harmonization of the legislation of Ukraine with the legislation of the European Union

A number of acts were adopted in implementation of the Association Agreement by the Cabinet of Ministers of Ukraine among which the September 17, 2014 decree of the Cabinet of Ministers of Ukraine "On Implementation of the Association Agreement between Ukraine from one side and the European Union, the European Atomic Energy Community, and their Member States from another side, was approved the Implementation Plan for 2014-2017 [19]. This Plan contained 488 points, which indicated the extent of the requirements that Ukraine has to fulfill in order to bring the legislation of Ukraine into compliance with the requirements of the European Union. The activities are divided into six sections that are relevant to the Association Agreement, namely "General Objectives and Principles", "Political Dialogue and Reforms, Political Association, Cooperation and Convergence in Foreign Affairs and Security Policy", "Justice, Freedom and Security", "Trade and Trade-Related Issues", "Economic and Sectoral Cooperation", "Financial Cooperation". It was subsequently replaced by the Action Plan on the Implementation of the Association Agreement between Ukraine, of the one part, and the European Union, the European Atomic Energy Community, and their Member States, of the other part [20], adopted in 2017, which contained 1943 tasks, the provisions of the Association Agreement/Decision of the Association Council which are the basis for such task, the applicable EU law, the name of the measures, and the authorities responsible for their implementation. The main ones related to constitutionalism include the following:

1. The creation of legal preconditions for the commencement of the reform of local selfgovernment and territorial organization of power and ensuring for this support consideration by the Verkhovna Rada of Ukraine of the draft Law of Ukraine "On Amendments to the Constitution of Ukraine (on Decentralization of Power)" (p. 1);

2. To adopt basic laws on reforming the system of civil service and service in local selfgovernment bodies and ensuring support by the Verkhovna Rada of Ukraine to consider the new version of the Law of Ukraine "On Service in Local Self-Government Bodies (p. 2);

3. Implementation of public administration reform (p. 3);

4. Legislative support for the reform of local self-government and territorial organization of government (p. 4);

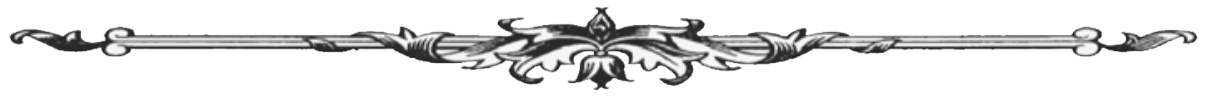


5. Harmonization of electoral legislation through its codification (p. 7);

6. Reforming the procedure for abolishing parliamentary immunity(p. 10);

7. Ensuring the functioning of the National Agency on Corruption Prevention (p. 13);

8. Improving anti-discrimination legislation on countering multiple discrimination (p. 21)

9. Ratification of the Council of Europe Convention on the prevention and combat violence against women and domestic violence (Istanbul Convention) (p. 22);

10. Establishment of the Institute for Government Commissioner for Gender Policy (p. 24);

11. Improvement of mechanisms for combating torture and ill-treatment people (p. 31);

12. Legislative consolidation of guarantees of freedom of peaceful assemblies (p. 34);

13. A number of anti-corruption initiatives (p. 38, 39, 40, 43, 59);

14. Ratification of the Rome Statute of the International Criminal Court (p. 61) and others.

Thus, there are a number of measures relevant to constitutionalism that are envisaged by the Plan concerning human rights, anti-corruption legislation, electoral legislation, decentralization reform, and other areas. The President of Ukraine, by decree of April 20, 2019, also approved the Plan of Measures for Implementation of the State's Strategic Course for Acquiring Full Membership of Ukraine in the European Union and in the North Atlantic Treaty Organization [21].

Attention should also be drawn to the annual reports on the implementation of the Association Agreement between Ukraine and the European Union, which are being prepared by the Government Office for Coordination of European and Euro-Atlantic Integration with the support of the Office of the Vice Prime Minister for European and Euro-Atlantic Integration of Ukraine and the EU Association4U. In particular, the 2018 Report [22] indicates that, based on the performance of the tasks scheduled for 2018, the Agreement was completed by $52 \%$, and the tasks of the Agreement that were not completed in previous years (p.4) are being gradually fulfilled. Overall progress in Ukraine's implementation of the Association Agreement is estimated at $42 \%$, including $28 \%$ by the Verkhovna Rada, $43 \%$ by central executive bodies and $34 \%$ by other state authorities (p. 9). Regarding the institutional support for the implementation of the Association Agreement, the following are envisaged:

1. At Government level: Vice Prime Minister for European and Euro-Atlantic Integration of Ukraine, who is involved in the political direction of the Government's activities; Government Office for the Coordination of European and Euro-Atlantic Integration, which deals with organizational, expert-analytical and information support of the activities of the Cabinet of Ministers of Ukraine; The Governmental Committee on European, Euro-Atlantic Integration, International Cooperation, and Regional Development, which serves as a platform for decisions discussions;

2. At parliamentary level: Committee of the Verkhovna Rada of Ukraine on European Integration;

3. At the Ministry level: posts of the Deputy Minister for European Integration, who ensure the implementation of the action plan, the responsible person of the executive authorities who deals with the organizing comprehensive reports in the framework of the reporting on the implementation of the Agreement and the Directorate for Strategic Planning and European Integration (p. 11).

Thus, institutional preconditions for proper implementation and implementation of the Association Agreement have been created in Ukraine. Procedural aspects of adopting acts by public authorities are also important, as exemplified by the mechanism of elaboration on compliance with Ukraine's commitments in the field of European integration and EU law, as envisaged by the Cabinet of Ministers of Ukraine Regulation [23]. In particular, the draft resolution of the Cabinet of Ministers, as well as the draft decree of the Cabinet of Ministers on approving the concept of implementation of state policy in the relevant sphere, the concept of the state target program and the concept of law, are subject to consideration for compliance with Ukraine's obligations in the field of European integration, including international law and subject to European Union law (EU acquis) (paragraph 1, paragraph 35 of the Regulation). The developer, according to paragraph 2 par. 35 of the Regulation defines (1) the sources of European Union law (EU acquis) governing legal relationships, similar to those intended to be settled by a draft act; (2) the existence of obligations of Ukraine in the field of European integration, including international law, regarding the subject

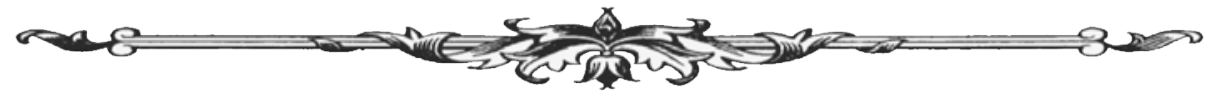


of legal regulation of the draft act; (3) availability of program documents in the field of European integration in the subject matter regulated by the draft act; conducts (4) comparative and/or comparative legal analysis; and (5) provides justification in case of incompatibility of the draft EU acquis with international agreements in the field of European integration, provides for its validity. Thus, there is a mandatory procedure for verifying compliance with the commitments on European integration, which promotes the proper implementation of the Association Agreement. However, the weak point is the passage of the necessary decisions in the country's parliament [22, p. 11].

In the context of European integration, Ukraine-EU annual summits are also important, which are the highest level of political dialogue [24]. It also provides for the establishment of an Association Board, which oversees and monitors the implementation of the Association Agreement and periodically reviews the functioning of the Agreement in the light of its objectives. The Council on the Ukrainian side includes members of the Cabinet of Ministers of Ukraine, and on the EU side, members of the Council of the European Union and the European Commission [25]. Thus, according to Art. 461 Association Agreements, Association Council meetings are held regularly at ministerial level at least once a year, and when circumstances warrant. By mutual agreement, meetings of the Association Council shall be held in any necessary composition. To the assistance of the Association Council, there is also the Association Committee (under Article 464 of the Association Agreement), which is the highest body of the association at the expert level, includes representatives of ministries, mainly at the level of Ministers' Deputies on European Integration [26].

Within the framework of harmonization of the legislation of Ukraine with the law of the European Union, a methodology for checking compliance with EU legislation and compiling tables of conformity [27] has been developed, the purpose of which is to help Ukrainian civil servants to develop legislative acts, draw up and use compliance tables and carry out compliance checks (p. 1) Methodologies). Recommendations have also been created for Ukrainian public authorities on approximation to EU law [28], developed within the framework of the EU project "Supporting the Implementation of the Association Agreement between Ukraine and the EU" (hereinafter referred to as "Association4U"), implemented by a consortium led by GFA Consulting Group, in cooperation with the EU / UNDP Council on Europe: Capacity Building in Support of the Verkhovna Rada of Ukraine, and with the consultative support of the Government Office for Coordination of European and Euro-Atlantic Integration of the Cabinet of Ministers of Ukraine. which also provides an overview of the case-law of the Court of Justice in the areas covered by the Association Agreement between Ukraine and the EU, the organization of the process of approximation to EU law in Ukraine, instructions for the use of EU law databases.

Thus, we can draw the following conclusions. There has been an increase in European integration processes in Ukraine since 2014, which is connected with the signing of the Association Agreement between Ukraine and the European Union. We can distinguish the following areas in which the process of European integration is taking place:

1. The amendments to the Constitution of Ukraine analyzed above. Despite some criticism of these changes (including, in part, the amendment to the Constitution's Preamble and the absence of changes to Section I), we support them as positive at this stage. Foreign practice shows that if Ukraine approaches the formal EU membership, the following changes will be needed in terms of the transfer of sovereign powers, bringing EU norms into compliance. However, at the moment the consolidation of the strategic course on European integration among the powers and status of the President of Ukraine, the Verkhovna Rada of Ukraine, the Cabinet of Ministers of Ukraine allows to pay additional attention and to oblige the above-mentioned bodies and officials by the norms of direct action;

2. Creation of institutional mechanisms for European integration, which can be divided into (i) external ones, through which Ukraine and the EU cooperate on issues such as the EU-Ukraine Summit, the Association Council and the Association Committee; and (ii) internal ones created within the Ukrainian Parliament and the Government to pay attention and verify compliance with the Association Act, which is being adopted - is the post of Vice Prime Minister for European

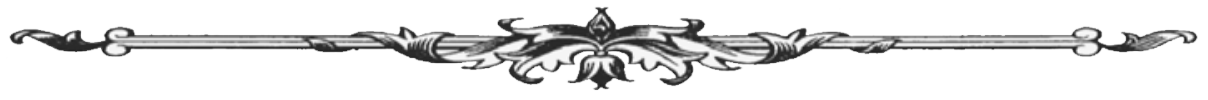


and Euro-Atlantic Integration, a government office Coordination of European and Euro-Atlantic Integration, Governmental Committee on European, Euro-Atlantic Integration, International Cooperation, and Regional Development, Verkhovna Rada of Ukraine Committee on European Integration and Minister for European Integration, Directorate of Strategic Planning and European integration. The creation of such a large number of institutional mechanisms in a short period of time indicates the existence of real intentions for the implementation and implementation of the Association Agreement;

3. Creation of legal mechanisms within the framework of lawmaking, such as the obligatory review of acts of the Cabinet of Ministers of Ukraine for compliance with Ukraine's commitments in the field of European integration and the European Union law (EU acquis);

4. Adoption of action plans at the level of the Cabinet of Ministers of Ukraine and the President of Ukraine for the implementation of the Association Agreement;

5. Implementation of measures on the implementation of the Association Agreement, adoption of necessary laws and by-law acts.

On the whole, we value the above areas positively, as their totality enables comprehensive and proper implementation of the European integration, which brings Ukraine closer to various fields, including human rights, good governance, effective anti-corruption policy, public administration, and local self-governance reforms to European standards which are already implemented within the European Union and the EU acquis.

\section{References:}

1. Association Agreement between the European Union and its Member States, of the one part, and Ukraine, of the other part, 2014. URL: http://eeas.europa.eu/ukraine/docs/association agreement_ukraine_2014_en.pdf

2. Закон України «Про засади внутрішньої і зовнішньої політики» від 1 липня 2010 p. URL: https://zakon.rada.gov.ua/laws/show/2411-17/print

3. Закон України «Про внесення змін до Конституції України (щодо стратегічного курсу держави на набуття повноправного членства України в Європейському Союзі та в Організації Північноатлантичного договору)» від 7 лютого 2019 p. URL: https://zakon.rada.gov.ua/laws/show/2680-19\#n6

4. Висновок конституційного суду України у справі за конституційним зверненням Верховної Ради України про надання висновку щодо відповідності законопроекту про внесення змін до Конституції України (щодо стратегічного курсу держави на набуття повноправного членства України в Свропейському Союзі та в Організації Північноатлантичного договору) (реєстр. № 9037) вимогам статей 157 і 158 Конституції України № 3-в/2018 від 22 листопада 2018 p. URL: https://zakon.rada.gov.ua/laws/show/v003v710-18

5. Окрема думка судді Конституційного Суду України Гультая М.М. щодо Висновку Конституційного Суду України у справі за конституційним зверненням Верховної Ради України про надання висновку щодо відповідності законопроекту про внесення змін до Конституції України (щодо стратегічного курсу держави на набуття повноправного членства України в Європейському Союзі та в Організації Північноатлантичного договору) (реєстр. № 9037) вимогам статей 157 і 158 Конституції України від 22 листопада 2018 року № 3-в/2018. URL: https://zakon.rada.gov.ua/laws/show/nc03d710-18\#n2

6. Окрема думка судді Конституційного Суду України Мельника М.I. стосовно Висновку Конституційного Суду України у справі за конституційним зверненням Верховної Ради України про надання висновку щодо відповідності законопроекту про внесення змін до Конституції України (щодо стратегічного курсу держави на набуття повноправного членства України в Європейському Союзі та в Організації Північноатлантичного договору) (реєстр. № 9037) вимогам статей 157 і 158 Конституції України. URL: https://zakon.rada.gov.ua/laws/ show/nd03d710-18\#n2

7. Висновок Конституційного Суду України у справі за зверненням Верховної Ради України про надання висновку щодо відповідності проекту Закону України «Про внесення

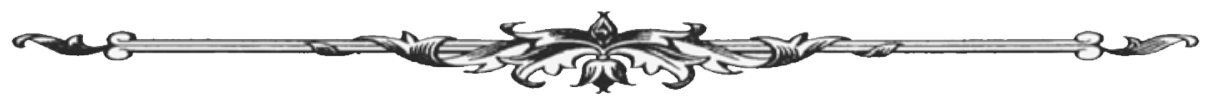


змін до статті 46 Конституції України» вимогам статей 157 і 158 Конституції України (справа про внесення змін до статті 46 Конституції України) N 2-в/99 від 2 червня 1999 р. URL: https://zakon.rada.gov.ua/laws/show/v002v710-99

8. Окрема думка судді Конституційного Суду України Касмініна О.В. стосовно Висновку Конституційного Суду України у справі за конституційним зверненням Верховної Ради України про надання висновку щодо відповідності законопроекту про внесення змін до Конституції України (щодо стратегічного курсу держави на набуття повноправного членства України в Свропейському Союзі та в Організації Північноатлантичного договору) (реєстр. № 9037) вимогам статей 157 і 158 Конституції України. URL: https://zakon.rada.gov.ua/laws/ show/ne03d710-18\#n2

9. Окрема думка судді Конституційного Суду України О.М. Литвинова стосовно Висновку Конституційного Суду України у справі за конституційним зверненням Верховної Ради України про надання висновку щодо відповідності законопроекту про внесення змін до Конституції України (щодо стратегічного курсу держави на набуття повноправного членства України в Свропейському Союзі та в Організації Північноатлантичного договору) (реєстр. № 9037) вимогам статей 157 і 158 Конституції України. URL: https://zakon.rada.gov.ua/laws/ show/nf03d710-18\#n2

10. Окрема думка судді Конституційного Суду України Первомайського О.О. стосовно Висновку Конституційного Суду України у справі за конституційним зверненням Верховної Ради України про надання висновку щодо відповідності законопроекту про внесення змін до Конституції України (щодо стратегічного курсу держави на набуття повноправного членства України в Свропейському Союзі та в Організації Північноатлантичного договору) (реєстр. № 9037) вимогам статей 157 і 158 Конституції України. URL https://zakon.rada.gov.ua/laws/ show/ng03d710-18\#n2

11. Окрема думка судді Конституційного Суду України Тупицького О.М. стосовно Висновку Конституційного Суду України у справі за конституційним зверненням Верховної Ради України про надання висновку щодо відповідності законопроекту про внесення змін до Конституції України (щодо стратегічного курсу держави на набуття повноправного членства України в Свропейському Союзі та в Організації Північноатлантичного договору) (реєстр. № 9037) вимогам статей 157 і 158 Конституції України. URL: https://zakon.rada.gov.ua/laws/ show/nh03d710-18\#n2

12.Демченко I.C. Угода про Асоціацію між Україною та ЄC: перспективи. Науковий Вісник Ужгородського національного університету. Серія Право. 2016. Вип. 41. Т. 2. C. 211-216. URL: http://www.visnyk-juris.uzhnu.uz.ua/file/No.41/part_2/52.pdf

13. Чернадчук О.В. Адміністративно-правові засади імплементації економічної частини угоди Україна-СС. Юридичний науковий електронний журнал. 2018. № 5. C. 145-148. URL: http://www.lsej.org.ua/5 2018/40.pdf

14.Рагуліна К.А. Угода про Асоціацію як правова основа адаптації законодавства України до законодавства Європейського Союзу. Науковий вісник Херсонського Національного університету. Серія Юридичні Науки. 2016. Випуск 1. Т. 1. С. 50-54. URL: http://www.lj.kherson.ua/2016/pravo01/part_1/15.pdf

15.Яворська I. Правові засади імплементації угоди про асоціацію України з Свропейським Союзом у сфері регулювання діяльності товариств. Вісник Львівського національного університету. Серія Міжнародні відносини. 2018. Випуск 44. С. 183-192. URL: http://publications.lnu.edu.ua/bulletins/index.php/intrel/article/view/9468/9497

16.Мелех Л.В. Окремі питання імплементації законодавства Свропейського Союзу в земельне законодавство України. Науковий вісник Львівського державного університету внутрішніх справ. 2018. № 2. C. 125-134. URL: http://www2.lvduvs.edu.ua/documents_pdf/ visnyky/nvsy/nvsy_02_2018/16.pdf

17.Подорожня Т. Проблеми оновлення Конституції України та національного законодавства в контексті підписання Угоди про Асоціацію між Україною та СС. Віче. 2015. № 6. C. 27-31.

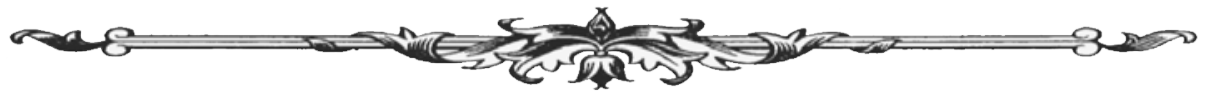


18.Білак М.В. Значення Угоди про Асоціацію з СС: нові виклика для конституційнго порядку чи послаблення позиції основного закону. Наукові записки НаУКМА. 2017. Том 193: Юридичні науки. С. 12-16. URL: http://ekmair.ukma.edu.ua/bitstream/ handle/123456789/12461/Bilak_Znachennia_Uhody.pdf

19. Розпорядження Кабінету Міністрів України від 17 вересня 2014 р. «Про імплементацію Угоди про асоціацію між Україною, з однієї сторони, та Європейським Союзом, Свропейським Співтовариством $з$ атомної енергії і їхніми державами-членами, з іншої сторони» від 17 вересня 2014 p. URL: http://zakon4.rada.gov.ua/laws/show/847-2014-\%D1\%80

20. Постанова Кабінету Міністрів України «Про виконання Угоди про асоціацію між Україною, з однієї сторони, та Європейським Союзом, Свропейським співтовариством з атомної енергії і їхніми державами-членами, з іншої сторони» від 25 жовтня 2017 р. № 1106. URL: https://zakon.rada.gov.ua/laws/show/1106-2017-\%D0\%BF

21. Указ Президента України «Питання європейської та євроатлантичної інтеграції» від 20 квітня 2019 року № 155/2019. URL: https://zakon.rada.gov.ua/laws/show/155/2019

22.3віт про виконання Угоди про асоціацію між Україною та європейським союзом у 2018 році. URL: https://eu-ua.org/sites/default/files/inline/files/association-agreementimplementation-report-2018.pdf

23. Регламент Кабінету Міністрів України, затверджений Постановою Кабінету Міністрів України від 18 липня 2007 р. № 950 (у редакції постанови Кабінету Міністрів України від 9 листопада 2011 р. № 1156). URL: https://zakon.rada.gov.ua/laws/show/950-2007-\%D0\%BF

24.Саміт Україна - СС. Євроінтеграційний портал. URL: https://eu-ua.org/samitukrayina-yes

25. Рада асоціації. Євроінтеграційний портал. URL: https://eu-ua.org/rada-asociaciyi asociaciyi

26. Комітет асоціації. Свроінтеграційний портал. URL: https://eu-ua.org/komitet-

27. Методологія перевірки відповідності законодавству ЄС і складання таблиць відповідності. URL: https://eu-ua.org/sites/default/files/imce/metodologiya-perevirki-vidpovidnostizakonodavstvu-yes-i-skladannya-tablic-vidpovidnosti-a4u.pdf

28. Рекомендації для українських органів державного управління щодо наближення до права CC. URL: https://eu-ua.org/sites/default/files/inline/files/legal_approximation_guidelines ukr_new.pdf

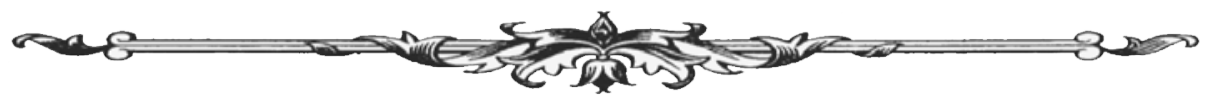

